\title{
大学生における身近な友人の抑うつ症状への 情緒的巻き込まれの恐れ
}

——楽観的見通し，深刻度評価，専門家への援助要請の必要性との関連—

\author{
河 合 輝 久*
}

本研究の目的は, 身近な友人の抑うつ症状への情緒的巻き込まれの恐れが当該友人に対する楽観的見 通し，深刻度評価，専門家への援助要請の必要性に及ぼす影響を検討することであった。大学生 1,000 名 (有効回答者 866 名) を対象に質問紙調查を実施した。その結果, 「直面化回避志向」と「共鳴懸念」の 2 因子から成る身近な友人の抑うつ症状への情緒的巻き込まれの恐れ尺度を作成し，その信頼性と妥当 性の一部が確認された。また，直面化回避志向および共鳴懸念が，原因帰属や楽観的見通しを介して， 深刻度評価および専門家への援助要請の必要性に及ぼす影響を検討した。共分散構造分析の結果, うつ 病事例に対する認知の可否にかかわらず，直面化回避志向は，抑うつ症状を示す友人に対する楽観的見 通しと有意な正の関連を，当該友人に対する梁刻度評価と有意な負の関連を示していた。一方，共鳴懸 念は，抑うつ症状を示す友人に対する深刻度評価と有意な正の関連を示していた。身近な友人の抑うつ 症状に対する評価において, 身近な友人の抑うつ症状への情緒的巻き込まれの恐れのうち, 直面化回避 志向は深刻視を妨げ，共鳴懸念は深刻視を促すことが示唆された。

キーワード : 大学生, 友人, 抑うつ症状, 情緒的巻き込まれの恐れ

\section{問 題}

平均して約三割の大学生が抑うつ症状を経験してい ることを示唆するエビデンスが蓄積されており（Ibrahim, Kelly, Adams, \& Glazebrook, 2013)，大学生において抑 うつ症状は稀ではない。抑うつ症状は大学生の学業 の支障になり (American College Health Association, 2008)， 抑うつ症状を主とするうつ病は自殺の背景因子であ る (Uchida \& Uchida, 2017)。そのため, うつ病の徵候や 症状の早期発見と介入が重要であるが, 大学生はう つ病を呈しても専門家に援助を求めにくい (Eisenberg, Golberstein, \& Gollust, 2007)。この理由の一つとして, 大 学生は友人よりも自らが抑うつ症状を呈した場合, そ の重症度や専門家への援助要請の重要性を過小評価す る (Spendelow \& Jose, 2010; 梅垣・木村, 2012) ことが挙げら れる。これは, 抑うつ症状を呈した大学生は, 自らの 現状を重大視し難く, 周囲の友人の方が, 相対的に客 観視できることを示唆している。つまり，身近な友人 は大学生のうつ病の早期発見の援助資源として期待さ れる。実際，うつ病事例を “Depression”や やdepressed”

山形大学

(前所属 : 東京大学学生相談ネットワーク本部ピアサポート ルーム)
と記述分類する者ほど，「判断せずに話を聴く」や「他 者のサポートを得るよう勧める」といった初期援助を 意図しやすい (Yap, Reavley, \& Jorm, 2015)。また, 複数の 選択肢の中から “Depression”を選択する者ほど, 専門 的な援助を求めるべきと考えやすい (Kim, Saw, \& Zane, 2015)。さらに, 河合 (2019) は, うつ病事例を「うつ病 にかかっている」と認知する大学生は, そうでない大 学生に比べ, 自身の心身の健康を尊重しつつ, 推奨さ れている初期援助を意眓することを報告している。以 上から, うつ病の徵候や症状を呈する大学生の身近な 友人が，うつ病を認知できることは，自身のメンタル ヘルスを保持しながら適切な初期援助を実行しやすい 点でメリットがある。

しかし一方で，抑うつ症状を呈していない一般の 人々や友人のような身近な周囲の人々にとっても, 抑 うつ症状を呈する者の深刻さを客観的に評価すること が必ずしも容易でないことも示されている。従来の抑 うつ症状に対する援助要請研究では, 友人が中程度の 抑うつ状態（9つの抑うつ症状を呈する状態）である仮想場 面に対して，回答者の当該友人に対する深刻度評価は 7 点中 4 点台であり, 必ずしも深刻視されていなかっ た (e.g., Spendelow \& Jose, 2010; 梅垣・木村, 2012)。抑うつ 症状を呈する者への深刻度評価について, うつ病の病 
因論に対する信念やスティグマに関する先行研究から, うつ病の状態や症状を示す者への原因帰属の仕方や否 定的認識が，その者に対する梁刻度評価に関連するこ とが示唆されている。Cook \& Wang (2011) や Reavley \& Jorm（2014）は，うつ病は神経質な人がなる，性格が 弱い人がなるといった原因带属をする人ほど，うつ病 罹患者に対して個人的な弱さの表れといった認識を抱 きやすいとしている。また，そのように認識している 若者ほど，うつ病罹患者に「しっかりしろときつく言 う」ことや「問題を忘れさせるために飲酒を勧める」 ことを意図しており (Yap \& Jorm, 2011), 精神科医や力 ウンセラーなどの専門家による介入が罹患者に役立つ と認識していなかった (Yap, Wright, \& Jorm, 2011)。さら に, Goldstein \& Rosselli (2003) は, うつ病の病因を心 理的要因に帰属している大学生ほど, うつ病に対して 自力での対処を有効とみなしていることを明らかにし ている。以上の先行研究から, 抑うつ症状を呈する者 の身近な周囲の人々が, 当該抑うつ者の深刻さを評価 する際，その者の現状をどのような原因に帰属するか, その者にどのような否定的認識を抱くかが影響するこ とが示唆される。このような示唆は, 抑うつ症状を呈 する者の身近な周囲の人々を援助資源として機能させ ることを目的とした予防的介入上重要である。しかし, Goldstein \& Rosselli (2003) を除く上記の先行研究では, うつ病罹患者が描かれた想定場面が用いられており， 身近な周囲の人々の抑うつ症状を呈する者への認識抒 よび評価の実際を理解するには限界がある。また，抑 うつ症状を呈する者への否定的認識の内容は, 統合失 調症に対するものに基づいており，十分に検討されて いないため, その妥当性には限界がある（樫原・河合・ 梅垣, 2014)。

このような限界を受け, 河合 (2016) は, 実際に抑う つ症状を呈する友人がいた大学生に対して, インタ ビュー調査を実施し, 大学生が当該友人の抑うつ症状 を見過ごす過程を質的に分析している。その結果，原 因帰属やそれに基づく評価があり, 当該友人への否定 的認識が関連するという仮説を生成している。具体的 には，大学生は，抑うつ症状を呈する友人の現状を当 該友人の元々の性格・行動傾向に内的原因帰属したり, 同年代にありがちな問題であるとみなしたりすると， 楽観的に見通し, 深刻視しない。また, 当該友人が置 かれている状況や環境に外的原因帰属しても, 当該友 人自身で自己解決できると期待すると, 軽視し，その 原因を解決しにくいと考えると, 当該友人の症状や状 態を心配することにとどまる。さらに, 大学生は, 当
該友人との関わりの中で情緒的に巻き込まることを恐 れること（以下，情緒的卷き込まれの恐れ）によって，当該 友人の健康的に保たれている側面に着目して, 抑うつ 症状を見過ごす。情緒的巻き込まれの恐れについて， 河合（2016）は，「心身に不調を来している友人に情緒 的に巻き込まれてしまうのではないかという恐れ」(河 合, 2016, p. 18) と定義している。これは, 抑うつ症状を 呈する者との接触に関する心配, 不安や戸惑いといっ た点で, 吉岡・三沢 (2012) や望月他 (2008) が示唆す るうつ病䍜患者への否定的認識内容と共通する構成概 念と捉えられる。吉岡 ·三沢 (2012) は, うつ病は以前 に比し身近な病になりつつあるため, うつ病罹患者に 対する否定的認識（危険性）には，重篤化し自死に至る 心配や対処の適切性への不安などの「多方面での“心 配” ‘ “不安”」(吉岡・三沢, 2012, p. 100) が包含されて いると指摘している。また, 望月他（2008）による調査 では，著しく偏見や差別を示す調查協力者は多くなく， 罹患者との付き合いに伴う不安や戸惑いに関する項目 に対して,「そう思う」と回答した調查協力者が比較的 多かった。従来, うつ病やその罹患者に対して, 非罹 患者が抱く否定的認識として,「しょうと思えば，抜け 出すことができる」,「個人的な弱さの表れである」, 「本当の医学的な病気ではない」,「うつ病䍜患者は危険 である」などの内容が取り上げられてきた（e.g., Griffiths, Christensen, Jorm, Evans, \& Groves, 2004; 吉岡 ·三沢, 2012)。しかし, これらの内容は, 先述の樫原他 (2014) による指摘の通り, うつ病の状態や症状を呈する者に 向けられる特有の内容ではない点で限界がある。実際, Griffiths et al. (2006) による調査では, これらの項目に 対して，「強く賛成する」や「賛成する」と回答した調 査協力者は半数未満であった。これは, 従来想定され てきたうつ病罹患者に対する否定的認識が必ずしも代 表的なものではなく, 異なる認識内容が別に存在する ことを示唆している。そのため, 従来の否定的認識内 容とは異なる概念として, 河合 (2016) が抑うつ症状を 呈する身近な友人がいた大学生の視点から帰納的に見 出した「情緒的巻き込まれの恐れ」に着目する意義が ある。しかし，これを測定する信頼性と妥当性を備え た尺度は作成されていない。身近な友人の抑うつ症状 に情緒的に巻き込まれることの恐れを測定し, 当該友 人の状態への評価に影響を及ぼすかを明らかにするこ とは, 大学生のうつ病の早期発見の援助資源として, 一般大学生を支援・教育する上での資料となる。その ため, 身近な友人の抑うつ症状への情緒的巻き込まれ の恐れを測定する尺度の作成は意義深いといえる。 
そこで, 本研究では, まず大学生の身近な友人の抑 うつ症状への情緒的巻き込まれの恐れ尺度を作成する。 その妥当性を検証するため, Messick (1995) の考え方 に基づき外的側面および構造的側面の証拠を確認する。 外的側面の検証のために「日本語版 Affective Control Scale」の下位尺度である抑うつ尺度（以下，日本語版ACS 抑うつ尺度とする; 金築・金築・及川, 2010)，不快情動回避心 性尺度（福森·小川, 2005), 情動的共感性尺度の下位尺度 である感情的被影響性尺度（加藤・高木, 1980）を用いる。 日本語版 ACS 抑うつ尺度は，自らの抑うつについて制 御不能になるのではないかという恐れを測定する尺度 である（金築他, 2010）。また, 不快情動回避心性尺度は, 抑うつ・不安といった不快な情動の回避心性を測定す る尺度である（福森・小川, 2005）。さらに, 情動的共感性 尺度は，他者からの感情的な影響の受けやすさを測定 する尺度である（加藤・高木, 1980)。これらを踏まえる と, 各尺度とも身近な友人への抑うつ症状への情緒的 巻き込まれの恐れ尺度と正の関連を示すと考えられる。

尺度を作成し, 妥当性 (外的側面の証拠) 及び信頼性を 検証した上で，次の 2 点を検証する。まず，抑うつ症 状を呈する友人を「うつ病にかかっている」と認知で きる群でも認知できない群でも，作成尺度において同 一の因子構造が認められるか, すなわち, 構造的側面 の証拠を検証する。そして，作成尺度と当該友人に対 する原因帰属や予後の評価, 当該抑うつ者への深刻度 評価との関連性を検討する。先行研究の概観から, 抑 うつ症状を呈する者への否定的認識は, その者に対す る原因帰属や予後の評価を介し, 当該抑うつ者への深 刻度評価に関連すると考えられる。しかし, 先行研究 には次の点で限界がある。第一に, 河合 (2016) が生成 した，抑うつ症状を呈する身近な友人との接触を通し て生じる「情緒的巻き込まれの恐れ」という構成概念 と当該友人への深刻度評価の関連は質的研究から得ら れた仮説にとどまっている点である。また，当該仮説 は, 主に当該友人をうつ病にかかっていると認知でき ていなかった大学生を対象とした質的研究から見出さ れたものである。そのため, うつ病にかかっていると 認知できる大学生も,「情緒的巻き込まれの恐れ」を抱 き，それによって抑うつ症状を呈する友人の深刻さを 過小評価することが量的に認められるかを検討する必 要がある。

仮想のうつ病罹患者をうつ病にかかっていると認知 できることは，罹患者に対する「危険」や「予測不能」 という否定的認識とは関連せず (Reavley, McCann, \& Jorm, 2012), 罹患者へのサポート意図とは有意な負の関連が
認められた（Amarasuriya, Reavley, Rossetto, \& Jorm, 2017)。 これらの知見は, 抑うつ症状を呈する友人をうつ病に かかっていると認知できる大学生は, 当該友人に対し て「危険」や「予測不能」という否定的認識を抱くわ けではないが, サポートを手控えるような意識を抱く ことを示唆している。先述した通り，吉岡・三沢 (2012) は, うつ病は身近な病になりつつあり, その罹 患者に対して, 身近な周囲の人々は「多方面での“心 配”や“不安”」（吉岡 ·三沢, 2012, p. 100）を抱く可能性 を指摘している。これらを踏まえると, うつ病にか かっていると認知できる大学生でも, 抑うつ症状を呈 する友人と接することで自らが情緒的に巻き达まれる かもしれないという心配である「情緒的巻き込まれの 恐れ」が生じ, 当該友人の深刻さを過少評価するとも 考えられる。また, 河合 (2016) は, 内的原因帰属, 問 題の一般性といった原因帰属やそれに基づく楽観的見 通しもまた抑うつ症状を呈する身近な友人の深刻さを 低く見積もる要因としており, 併せて量的に検討する 必要がある。先述の通り, うつ病の原因を心理的要因 に帰属する者ほど, うつ病の状態や症状を軽視した対 応をとったり，自力での対処が有効とみなしたりする。 一方, うつ病の原因を日々のストレスを含む外的事象 に原因帰属する者ほど, うつ病罹患者を危険と認知し 社会的距離をとろうとする（吉岡・三沢, 2012）。以上か ら, うつ病の認知の可否にかかわらず, 内的原因帰属 と問題の一般性は楽観的見通しに加え, 抑うつ症状を 呈する身近な友人への深刻度評価に負の関連を示し, 外的原因帰属は当該友人への深刻度評価に正の関連を 示すと考えられる。

また, 河合 (2016) による調査では原因帰属やそれに 基づく判断, 情緒的巻き込まれの恐れといった要因が 援助に繫がりうるかが不明である。援助に関する变数 として, 医療・ 心理援助の専門家への援助要請の重要 性（梅垣・木村, 2012）や受療の重要性（梅垣・末木, 2012） が取り挙げられてきた。特に後者の変数は, 抑うつ症 状を呈する友人に受療を勧める意図と正の関連が認め られているため (梅垣, 2014), 専門家への援助要請の必 要性として従属変数に加え関連性を検討する。先述の 議論を踏まえると, 情緒的巻き込まれの恐れ, 内的原 因帰属, 問題の一般性, 楽観的見通しは, 抑うつ症状 の軽視に, 外的原因帰属は, 抑うつ症状の重大視に繋 がると考えられる。そのため, 情緒的巻き达まれの恐 れ, 内的原因帰属, 問題の一般性, 楽観的見通しは, 専門家への援助要請の必要性とは負の関連を示すと考 えられる。一方, 外的原因帰属は, 専門家への援助要 
請の必要性とは正の関連を示すと考えられる。

\section{本研究の目的}

上述の問題意識に沿って, 本研究の目的は, 次の通 りである。まず，大学生における身近な友人の抑うつ 症状への情緒的巻き込まれの恐れを測定する尺度を作 成し，その妥当性と信頼性を検証する。また，その作 成尺度の因子構造がうつ病を認知できるか否かにかか わらず同一であるかを検証する。さらに，作成尺度と， 原因帰属や楽観的見通しといった変数と併せて, 当該 友人の抑うつ症状に対する深刻度評価，専門家への援 助要請の必要性との関連を検討する。なお，検証する 仮説をまとめると次の通りになる。

仮説 1 : 身近な友人の抑うつ症状への情緒的巻き込 まれの恐れ尺度は，日本語版 ACS 抑うつ尺度，不快情 動回避心性尺度, 情動的共感性尺度と正の関連を示す (仮説 1-1)。また, うつ病事例をうつ病にかかっている と認知できる群でもできない群でも作成尺度において 因子構造の同一性が確認される（仮説 1-2）。

仮説 2 : 身近な友人の抑うつ症状への情緒的巻き込 まれの恐れは, 内的原因帰属, 問題の一般性, 楽観的 見通しと正の関連を示す (仮説 2-1)。また, 深刻度評 価, 専門家への援助要請の必要性とは負の関連を示す (仮説 2-2)。

仮説 3 : 内的原因帰属と問題の一般性は, 楽観的見 通しと正の関連を, 深刻度評価, 専門家への援助要請 の必要性と負の関連を示し, 外的原因帰属は, 楽観的 見通しと負の関連を，深刻度評価，専門家への援助要 請の必要性と正の関連を示す (仮説 3-1)。楽観的見通し は, 深刻度評価, 専門家への援助要請の必要性と負の 関連を, 深刻度評価は, 専門家への援助要請の必要性 と正の関連を示す (仮説 3-2)。

\section{方法}

\section{調査対象者}

インターネット調査会社（株式会社クロス・マーケティン グ）にモニター登録している大学生 1,000 名（男性 500 名，女性 500 名）が web 上の質問紙調査に回答した ${ }^{1}$ 。そ のうち，各質問項目および各尺度に全て回答した 866 名（男性 433 名, 女性 433 名, 平均年齢 $21.32(S D=2.22)$ ) 分析対象者とした。対象者の内訳は, 学部 1 年生が

研究内容上, 質問紙を授業前後に一斉配布し, その場で回答 を求めるよりも, 個人にて回答可能な web 上の質問紙調查を実 施した方が，周囲の存在を意識した回答が反映され難いと考え られた。そのため, 本研究では, webを介した質問紙調查を用 いた。
183 名, 学部 2 年生が 184 名, 学部 3 年生が 171 名, 学 部 4 年生が 230 名, 学部 5 年生以上が 22 名, 大学院生 が76 名であった。本研究にて大学院生も調查対象に含 めた理由は, 西村・岩佐・田中・藤井・高山（2008）に よる報告を踏まえたためである。西村他（2008）は，国 内の 1 大学における健康診断に受診した大学生および 大学院生を対象に, うつ病の時点有病率および 12 力月 有病率を算出している。その結果, 対象校の健康診断 を受診した大学生および大学院生におけるうつ病の時 点有病率は $3.5 \%, 12$ 力月有病率が $4.0 \%$ であり, 日 本人成人よりも高い有病率であると考察している。な お, 同調査では大学院生における時点有病率は $5.4 \%$, 12 力月有病率が 4.0 - $6.3 \%$ であることが示されてお り, 大学院生においても, うつ病が稀ではなく, 抑う つ症状を呈する者との接触機会があることが示唆され ている。この現状を踏まえ, 本研究では調查対象に大 学院生も含めた。

\section{質問紙の構成}

「下記の事例について，『○さん』にあなたにとって 身近で仲のよい友人ひとりを当てはめて読んだ上，質 問に回答してください」と教示した上，うつ病の症状 を呈する人物が描かれた事例を提示し，下記の質問 項目や尺度に回答を求めた。事例に描かれる人物と の関係性について, 国外の先行研究 (e.g., Jorm, Blewitt, Griffiths, Kitchener, \& Parslow, 2005; Yap et al., 2015) では, 「長 らく知り合いで大切にしている ("someone you have known for a long time and care about")」と教示されている。また, 国内の先行研究 (e.g., 木村, 2015) では, 同じ大学で最も 仲のよい同性の友人を思い浮かべるよう教示されてい る。調查協力者が想定する友人との関係性について, 厳密に統制することは, 現実的に困難であったため, 上記の先行研究を参考に, 本研究では, 調查協力者の 親しい友人を一人に特定するよう教示した。

事例は「○さんは, この数週間というもの, かつて ないほど悲しくてみじめな感じがしていました。いつ も疲れが残っているのに熟眠できません。食欲もなく 体重が減りました。学業に集中ができず，単位も落と してしまっています。決定すべきことも先送りにして います。日常の授業さえ負担に感じています。○さん の親や友人もとても心配しています。」であった。本事 例は Jorm et al. (2005) による調査で使用された想定場 面を 18-25 歳向けに改訂した Jorm, Wright, \& Morgan （2007）のものを邦訳して作成した。Jorm et al. (2005) が 用いた事例は DSM- IV の大うつ病性障害と ICD-10のう つ病エピソードの診断基準を満たす内容であった。わ 
が国では企業の従業員を対象にした調査（中村・久田, 2008）で邦訳して用いられていたことからこの邦訳を参 考にした。

事例に対する認知 事例の人物の状態に対する認知 について, 中村・久田（2008）の一部を修正し,「大き なストレスを感じている」，「何か大きな悩みを抱えて いる」,「学業上の問題を抱えている」,「疲労困ぱい状 態」, 「ノイローゼ (神経症) である」,「うつ病にかかっ ている」,「統合失調症である」,「その他」の選択肢の 中から当てはまるもの一つを選択してもらった。

内的原因帰属の程度 回答者の身近な仲のよい友人 が事例のような状態になった場合, その原因が友人自 身にあるかを 5 件法（「1：全くそう思わない一 3 : どちらとも いえない一 5 ：とてもそう思う」）で尋ねた。

外的原因帰属の程度 回答者の身近な仲のよい友人 が事例のような状態になった場合, その原因が友人の 外側の環境や出来事にあるかを 5 件法（「1：全くそう思 わない一 3 : どちらともいえない一 5 ：とてもそう思う」）で尋ね た。

問題の一般性の程度 回答者の身近な仲のよい友人 が事例のような状態になった場合, その状態は大学生 によくあることかを 5 件法（「1：全くそう思わない一 3 ：ど ちらともいえない一 5 ：とてもそう思う」）で尋ねた。

楽観的見通しの程度 回答者の身近な仲のよい友人 の予後について, 事例のような状態になった場合, そ の友人の状態は時間が経てばよくなるか, その友人は 自力で解決できるかという 2 項目について 5 件法 (「1: 全くそう思わない一3：どちらともいえない一 5 ：とてもそう思 う」)で尋ねた。なお，2 項目に対する主成分分析の結 果, 第一主成分の寄与率が $71.36 \%$ であったとから 1 因子構造と判断し 2 項目の合計得点を楽観的見通し 得点とした。

深刻度評価 回答者の身近な仲のよい友人が事例の ような状態になった場合の深刻さを 5 件法 (「1: 全く深 刻でない一 3 : どちらともいえない一 5 ：とても深刻である」) で 尋ねた。

専門家への援助要請の必要性 回答者の身近な友人 が事例のような状態になった場合，その友人の状態は 大学の学生相談やカウンセラーなどによる専門家によ る援助が必要かを 5 件法（「1：全く必要でない一 3 : どちら ともいえない一 5 ：とても必要である」）で尋ねた。

身近な友人の抑うつ症状への情緒的巻き込まれの恐 れ尺度 大学生を対象とした身近な友人の抑うつ症状 への情緒的巻き込まれの恐れ尺度を新たに作成した。 河合（2016）による調查から見出された仮説的知見のう
ち，「情緒的巻き込まれの恐れ」に基づき 13 項目を生 成した。尺度に回答する際，回答者に対して，「もし， 身近な仲のよい友人が，『憂うつな気分が晴れない状態 が続いていたり，これまで楽しめていたことも楽しめ なくなったりして, 非常につらく感じたり, いつも通 りの生活に支障が出たりするような状態になった』時, あなた自身がどのように思うかあなたの意見をおたず ねします。下記のそれぞれの項目について, 最も当て はまる数字を選び，チェックをいれてください。」とい う教示文を示した。回答は 7 件法（「1: 全く当てはまらな い一 3 : どちらともいえない一7：非常にあてはまる」）で求め た。

日本語版 ACS 抑うつ尺度（金築他, 2010） Williams, Chambless, \& Ahrens (1997) が作成した感情への恐れ を測定する尺度の日本語版尺度であり，「怒り」，「ポジ ティブ感情」, 「抑うつ」, 「不安」の 4 つの下位尺度か ら成る (全 42 項目 7 件法)。本研究の目的に沿って「抑う つ尺度」(全 8 項目) を用いた。「1：あてはまらない一 4: どちらともいえない一7：ぴったり当てはまる」の 7 件法で回答を求めた。

不快情動回避心性尺度（福森・小川, 2005） 全 10 項目 1 因子構造尺度である。「1：全くあてはまらない一 4 ： どちらともいえない一7：非常にあてはまる」の 7 件法 で回答を求めた。

情動的共感性尺度（加藤・高木, 1980）「感情的暖か さ」, 「感情的冷淡さ」, 「感情的被影響性」の 3 つの下 位尺度から成る (全 25 項目 7 件法)。本研究の目的に沿っ て,「感情的被影響性」尺度 (5 項目) を用いた。「1：全 くちがうと思う一 4 : どちらともいえない一7：全くそ うだと思う」の 7 件法で回答を求めた。

以上に加え, 他の質問項目や尺度も含まれていたが, 本研究の目的に即したもののみ報告する。

\section{分析手続き}

身近な友人の抑うつ症状への情緒的巻き込まれの恐 れ尺度に対して, 探索的因子分析を行った。探索的因 子分析では, 固有值の減衰状況, カイザー基準, スク リー基準，解釈可能性から因子構造を検討した。また， 作成尺度の信頼性は, $\alpha$ 係数を, 妥当性（外的側面の証 拠）は, 日本語版 ACS 抑うつ尺度, 不快情動回避心性 尺度, 感情的被影響性尺度との Pearsonの相関係数お よび偏相関係数を算出し検討した。探索的因子分析か ら得られた因子構造について, うつ病事例をうつ病と 認知できる大学生においても同一であるか（構造的側面 の証拠）を検討するため, 多母集団同時分析による確認 的因子分析を行った。その際, まず, うつ病事例に対 
する認知の可否について，「うつ病にかかっている」と いう選択肢を選択した者をうつ病認知群，それ以外の 選択肢を選択した者をうつ病未認知群に分類した。こ のような分類について, Kim et al. (2015) の分析手続き に倣った。問題にて述べた通り, うつ病事例に対して, 自由記述式回答でも選択式回答でも，うつ病であると 回答する者は，そうでない者に比へ，推奨されている 援助行動を実行すること (Kim et al., 2015; Yap et al., 2015), うつ病に対して適切な対処行動をとる可能性が高いこ と (中村·久田, 2008), 回答者自身の心身の健康を大切に することを意図する（河合, 2019）ことが報告されてい る。そのため, うつ病事例に対して,「うつ病にかかっ ている」と回答した者は, そうでない者に比心゙, 適切 な対応をとりうる点で, うつ病に関する知識を一定程 度備えていると判断した。なお, 適合度指標は, CFI, RMSEA を用いた。また，今後の資料として，探索的 に各変数のうつ病認知群とうつ病未認知群の差につい て, $t$ 検定 (Welch 法) を行い効果量 $d$ を算出した。さら に, 各変数間の相関係数を算出した。

作成尺度, 原因州属, 楽観的見通しが深刻度評価, 専門家への援助要請の必要性に関連する過程を検討す るため, 共分散構造分析を行った。各変数間の関連に ついて, 問題での議論に基づき，モデルを構成した。 まず，作成尺度から，原因帰属，楽観的見通し，深刻 度評価, 専門家への援助要請の必要性への関連を仮定 した。これは, うつ病の状態と症状を呈する者への否 定的認識によって, 当該人物への非援助行動が促され, 専門家による介入が役立つという認識が妨げられる (Yap et al., 2011) ためである。加えて, 大学生は, 抑う つ症状を呈する身近な友人に情緒的に卷き込まれるこ とを恐れ, 当該友人の健康的な側面に着目し, 抑うつ 症状を見過ごす（河合, 2016）という仮説的知見に基づ く。そして, 原因州属に関する変数から, 楽観的見通 し, 深刻度評価, 専門家への援助要請の必要性への関 連を仮定した。これは, うつ病の状態や症状の原因に ついて, 内的要因に帰属する者ほど，深刻視せず（河 合, 2016)，自力で対処を有効とみなす一方 (Goldstein \& Rosselli, 2003), 外的要因に帰属する者ほど, 危険視して いた（吉岡・三沢, 2012）ためである。また，楽観的見通 しから, 深刻度評価, 専門家への援助要請の必要性へ の関連を仮定した。これは，抑うつ症状を呈する友人 の状態を楽観的に見通すことで, 当該友人の深刻度を 過小評価する（河合, 2016）という仮説的知見に基づく。 さらに, 深刻度評価から専門家への援助要請の必要性 への関連を仮定した。これは, 抑うつ症状を示す友人
に対する深刻さの評価は，当該友人に受療を锥める意 図と有意な正の関連がある（梅坦, 2014）ためである。以 上の関連性を反映するために，作成尺度を第一水準， 内的原因㷌属, 外的原因帰属, 問題の一般性を第二水 準, 楽観的見通しを第三水準, 深刻度評価を第四水準, 専門家への援助要請の必要性を第五水準とするモデル を構成した。その際, 第一水準の全変数から第二水準 以降の全変数に, 第二水準の全変数から第三水準以降 の全変数に, 第三水準の変数から第四水準以降の全変 数に, 第四水準の変数から第五水準の変数に関連を設 定し, うつ病認知群・未認知群別に検討した。なお, モデルの適合度指標は，CFI， RMSEAを用いた。

\section{倫理的配慮}

本研究は著者の所属機関の研究倫理専門委員会の承 認を得て実施された。web 上の質問紙の冒頭に, 回答 は任意であり無記名式であること, 回答を拒否・中止 してもいかなる不利益も被らないことを明記した。ま た, 調查協力によって不快が生じた場合, 回答途中で も必要な治療・援助を受けられる援助資源の一覧を閲 覧できるようにした。さらに, 調查協力時点で身近に 心身の不調を来している者が抢り, 対応に苦慮してい る場合を踏まえ, 支援方法に関して情報提供を行って いる公的機関の web ページを調査協力終了時点で閲覧 できるようにした。

\section{結果}

\section{身近な友人の抑うつ症状への情緒的巻き込まれの恐れ 尺度の因子構造（仮説 1-1）}

身近な友人の抑うつ症状への情緒的巻き込まれの恐 れ尺度原案に対して, 探索的因子分析 (最尤法, プロマッ クス回転)を行った。その結果, 固有值の減衰状況 $(4.397,1.569,1.425,1.229,0.821,0.646 \cdots)$ からは 3 因子解, カイザー基準からは 4 因子解, スクリー基準からは 1 因子解あるいは 4 因子解が示唆された。また, 河合 （2016）によって生成された「情緒的巻き込まれの恐れ」 は 1 因子であることが理論的に考えられた。そのため, 1 因子解から 4 因子解を想定し, 各因子解に対して再 度探索的因子分析（最尤法, プロマックス回転）を行った。 その結果, 1 因子解と 3 因子解と 4 因子解では不適解 となった一方， 2 因子解では不適解とならなかったた め 2 因子解を採用した。Table 1 には因子負荷量が.40 未満の項目を削除した最終的な因子構造を示した。第 1 因子には，「接することを嫌に思う」や「目をそむけ たいと思う」など抑うつ症状を呈する身近な友人との 接触や当該友人の受容を回避しょうと考える項目を含 
Table 1 身近な友人の抑うつ症状への情緒的巻き込まれの恐れ尺度の因子分析結果

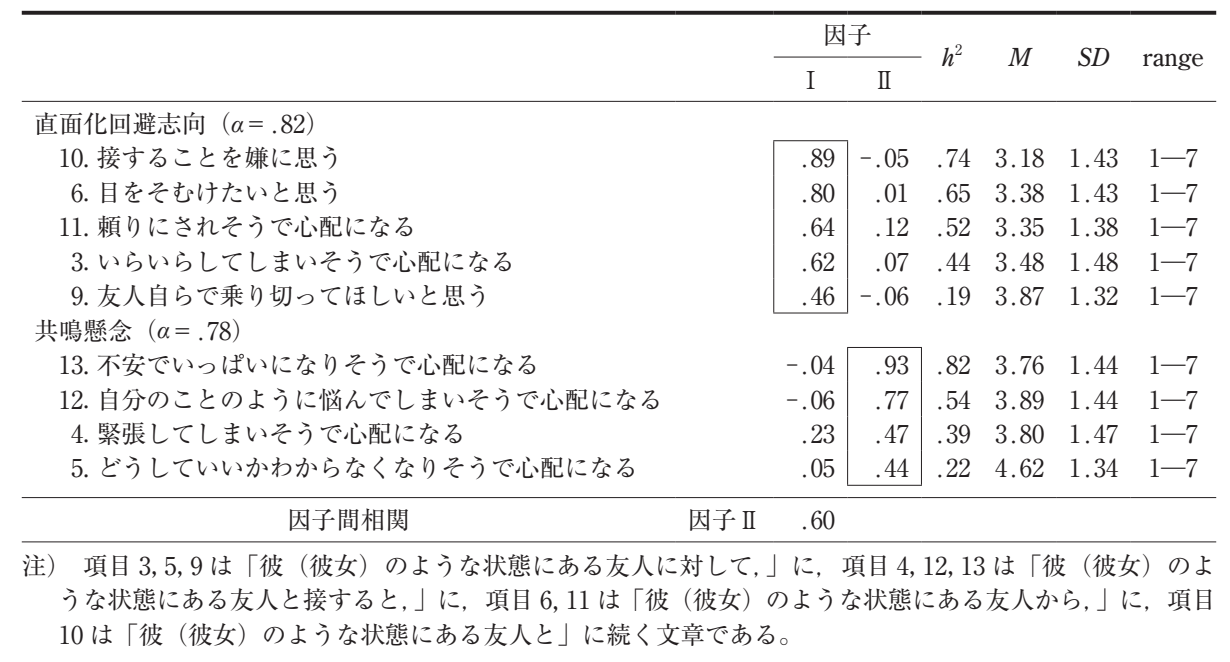

むことから,「直面化回避志向」と命名した。第 2 因子 には，「不安でいっぱいになりそうで心配になる」や 「自分のことのように悩んでしまいそうで心配になる」 など抑うつ症状を呈する身近な仲のよい友人との交流 を通して自らもネガティブな思考や感情を生じ動摇し てしまう懸念を示す項目を含むことから，「共鳴懸念」 と命名した。

\section{妥当性（外的側面の証拠）の検討（仮説 1-1）}

作成尺度の外的側面の証拠を検討するため, 理論的 に関連が想定される各尺度との相関係数を算出した。 また，共鳴懸念と直面化回避志向の間に有意な正の関 連が認められたため, 作成尺度の他の尺度得点を統制 した時の各尺度との偏相関係数を算出した。その結果, 共鳴懸念と日本語版 ACS 抑うつ尺度, 不快情動回避心 性尺度, 感情的被影響性尺度との間には有意な正の相 関 (順に, $r=.36, r=.48, r=.48$, 全て $p<.01$ ) および偏相 関が示された（順に, $p r=.38, p r=.33, p r=.42$, 全て $p<$ .001)。また, 直面化回避志向も各尺度との間に有意な 正の相関が示され（順に, $r=.07, p<.05 ; r=.41, p<.01$; $r=.27, p<.01)$, 不快情動回避心性尺度とも有意な正の 偏相関が示された $(p r=.21, p<.001)$ 。しかし, 日本語 版 ACS 抑うつ尺度との間には有意な負の偏相関が示さ れ $(p r=-.14, p<.001)$, 感情的被影響性尺度との間には 有意な関連が認められなかった $(p r=.03, n s) 。$

\section{作成尺度の因子構造の同一性（構造的側面の証拠）の検証} (仮説 1-2)

作成尺度の因子構造がうつ病認知群 -未認知群にお いて確認できるかを検証するために多母集団同時分析
による確認的因子分析を行った。まず，うつ病事例に 対する認知の可否別に分類した結果, うつ病認知群は 236 名, うつ病未認知群は 630 名であった。その上で, 因子負荷量および共分散に等值制約を置かない配置不 変モデルの適合度を算出した結果, $\mathrm{CFI}=.943$, RMSEA = .062であった。また, 因子負荷量および共 分散に等值制約を置いた測定不変モデルの適合度を算 出した結果, CFI=.941, RMSEA=.059であった。

\section{各尺度の記述統計}

身近な友人の抑うつ症状への情緒的巻き込まれの恐 れ尺度に加え, 各変数の記述統計を Table 2 に示した。 事例の認知の可否による差を検討した結果, うつ病未 認知群はうつ病認知群よりも, 問題の一般性と楽観的 見通しの得点が有意に高かった。また, 有意傾向では あるが, 内的原因帰属の得点もうつ病未認知群はうつ 病認知群よりも高かった。一方, 深刻度評価, 専門家 への援助要請の必要性の得点はうつ病認知群の方がう つ病未認知群よりも有意に高かった。また, 各変数間 の相関係数は Table 3 の通りであった。

情緒的巻き込まれの恐れ, 原因帰属, 楽観的見通しと 深刻度評価, 専門家への援助要請の必要性との関連（仮 説 2, 仮説 3)

仮定したモデルに対して共分散構造分析を行った。 有意傾向 $10 \%$ を満たさないパスを削除しながら分析 を繰り返し最終的に得られたモデルを Figure 1 に示 す。因子負荷量に等值制約を置かない配置不変モデル の適合度は $\mathrm{CFI}=.902, \mathrm{RMSEA}=.052$, 因子負荷量 に等值制約を置いた測定不変モデルは， CFI =.898, 
Table 2 全体, うつ病認知群とうつ病未認知群の各変数の記述統計量, Welch の検定結果

\begin{tabular}{|c|c|c|c|c|c|c|c|c|}
\hline & \multirow{2}{*}{ range } & \multicolumn{3}{|c|}{$M(S D)$} & \multicolumn{3}{|c|}{ Welch の検定 } & \multirow{2}{*}{$d$} \\
\hline & & 全体 & 認知群 & 未認知群 & $t$ & $d f$ & 差の $95 \% C I$ & \\
\hline 内的原因帰属 & $1-5$ & $\begin{array}{c}2.80 \\
(0.81)\end{array}$ & $\begin{array}{c}2.71 \\
(0.76)\end{array}$ & $\begin{array}{c}2.83 \\
(0.83)\end{array}$ & $2.04^{\dagger}$ & 458.31 & {$[.00, .24]$} & 0.15 \\
\hline 外的原因帰属 & $1-5$ & $\begin{array}{c}3.65 \\
(0.80)\end{array}$ & $\begin{array}{c}3.65 \\
(0.77)\end{array}$ & $\begin{array}{c}3.66 \\
(0.81)\end{array}$ & 0.12 & 445.91 & {$[-.11, .12]$} & 0.01 \\
\hline 問題の一般性 & $1-5$ & $\begin{array}{c}3.01 \\
(0.93)\end{array}$ & $\begin{array}{c}2.89 \\
(0.94)\end{array}$ & $\begin{array}{l}3.06 \\
(0.93)\end{array}$ & $2.31^{*}$ & 417.32 & {$[.02, .30]$} & 0.18 \\
\hline 楽観的見通し & $2-10$ & $\begin{array}{c}5.02 \\
(1.50)\end{array}$ & $\begin{array}{c}4.53 \\
(1.32)\end{array}$ & $\begin{array}{c}5.20 \\
(1.52)\end{array}$ & $-6.35^{* * *}$ & 483.87 & {$[-.87,-.46]$} & 0.46 \\
\hline 直面化回避志向 & $5-35$ & $\begin{array}{l}17.25 \\
(5.39)\end{array}$ & $\begin{array}{l}17.16 \\
(5.46)\end{array}$ & $\begin{array}{l}17.28 \\
(5.36)\end{array}$ & 0.29 & 415.55 & {$[-.70, \quad .93]$} & 0.02 \\
\hline 共鳴懸念 & $4-28$ & $\begin{array}{l}16.07 \\
(4.42)\end{array}$ & $\begin{array}{l}16.22 \\
(4.39)\end{array}$ & $\begin{array}{l}16.01 \\
(4.44)\end{array}$ & -0.61 & 425.77 & {$[-.87, .46]$} & 0.05 \\
\hline 媣刻度評価 & $1-5$ & $\begin{array}{c}4.14 \\
(0.74)\end{array}$ & $\begin{array}{c}4.26 \\
(0.61)\end{array}$ & $\begin{array}{c}4.09 \\
(0.78)\end{array}$ & $-3.34^{* *}$ & 533.08 & {$[-.27,-.07]$} & 0.23 \\
\hline 専門家への援助要請の必要性 & $1-5$ & $\begin{array}{c}3.98 \\
(0.85)\end{array}$ & $\begin{array}{c}4.27 \\
(0.76)\end{array}$ & $\begin{array}{c}3.87 \\
(0.86)\end{array}$ & $-6.75^{* * *}$ & 474.46 & {$[-.52,-.29]$} & 0.48 \\
\hline
\end{tabular}

${ }^{\dagger} p<.10 \quad * p<.05 \quad * * p<.01 \quad * * * p<.001$

Table 3 各変数間の相関係数

\begin{tabular}{|c|c|c|c|c|c|c|c|c|c|}
\hline & & 1 & 2 & 3 & 4 & 5 & 6 & 7 & 8 \\
\hline 1 & 内的原因㷌属 & & $-.19^{* *}$ & .03 & $.17^{* *}$ & $.21^{* *}$ & -.01 & $-.25^{* * *}$ & $-.25^{* * *}$ \\
\hline 2 & 外的原因㷌属 & $.11^{* *}$ & & .04 & $-.15^{*}$ & -.09 & -.04 & $.25^{* * *}$ & $.14^{*}$ \\
\hline 3 & 問題の一般性 & .07 & $.12^{* *}$ & & .05 & $14^{*}$ & $17^{*}$ & -.09 & .08 \\
\hline 4 & 楽観的見通し & $.29^{* * *}$ & $-.07^{\dagger}$ & $.12^{* *}$ & & $.16^{*}$ & -.01 & $-31^{* * *}$ & $-.33^{* * *}$ \\
\hline 5 & 直面化回避志向 & $.22^{* * *}$ & -.02 & .05 & $.25^{* * *}$ & & $38 * * *$ & $-.32^{* * *}$ & $-.24^{* * *}$ \\
\hline 6 & 共鳴懸念 & $.09^{*}$ & $.08^{*}$ & .03 & $.10^{*}$ & $.58^{* * *}$ & & .02 & .02 \\
\hline 7 & 深刻度評価 & -.05 & $.28^{* * * *}$ & .00 & $-.28^{* * *}$ & $-.20^{* * *}$ & $.10^{*}$ & & $.36^{* * *}$ \\
\hline 8 & 専門家への援助要請の必要性 & -.01 & $.20^{* * *}$ & -.01 & $-.25^{* * *}$ & $-.10^{*}$ & $.12^{* *}$ & $.45^{* * *}$ & \\
\hline
\end{tabular}

注） 右上半分がうつ病認知群, 左下半分がうつ病未認知群

${ }^{\dagger} p<.10 \quad * p<.05 \quad * * *<.01 \quad * * * p<.001$

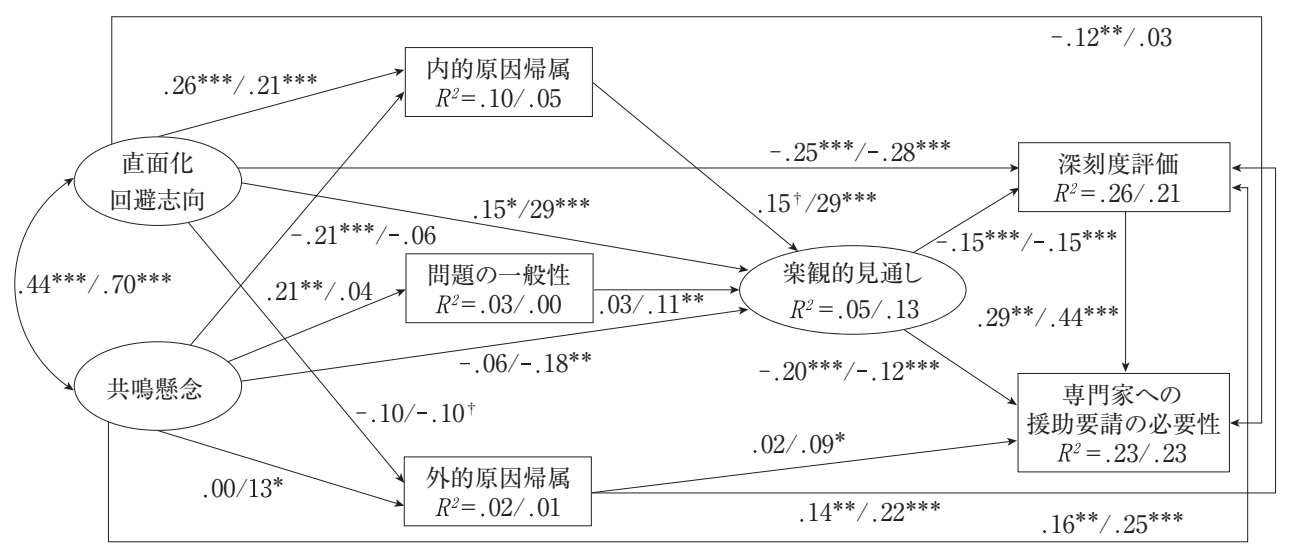

Figure 1 共分散構造分析の結果

注）／の左側はうつ病認知群，右側はうつ病未認知群の標準化推定值を示す。

「直面化回避志向」,「共鳴影念」,「楽観的見通し」の観測変数, 誤差変数, 両群とも有意でないパスは省略した。

${ }^{\dagger} p<.10 \quad * * p<.05 \quad * * p<.01 \quad * * * p<.001$ 
RMSEA=.051 であった。

身近な友人の抑うつ症状に対する情緒的巻き込まれ の恐れの各変数への関連は次の通りであった。うつ病 認知群では, 共鳴懸念は問題の一般性, 深刻度評価と 有意な正の関連を, 内的原因帰属と有意な負の関連を 示した。また，直面化回避志向は内的原因帰属，楽観 的見通しと有意な正の関連を, 深刻度評価，専門家へ の援助要請の必要性と有意な負の関連を示した。しか し, 同群では, 直面化回避志向は問題の一般性, 外的 原因帰属と, 共鳴懸念は外的原因帰属, 楽観的見通し, 専門家への援助要請の必要性と有意な関連を示さな かった。一方, うつ病未認知群では, 共鳴懸念は外的 原因帰属，深刻度評価と有意な正の関連を，楽観的見 通しと有意な負の関連を示した。また，直面化回避志 向は内的原因帰属, 楽観的見通しと有意な正の関連を 示し, 外的原因帰属と有意傾向の負の関連を示し, 深 刻度評価と有意な負の関連を示した。しかし, 同群で は, 直面化回避志向は問題の一般性, 専門家への援助 要請の必要性と有意な関連を示さなかった。

原因帰属から各変数への関連は次の通りであった。 うつ病認知群では, 内的原因帰属は楽観的見通しと有 意傾向の正の関連を示した。また，外的原因帰属は深 刻度評価と有意な正の関連を示した。しかし, 同群で は, 内的原因㛿属は, 深刻度評価, 専門家への援助要 請の必要性と, 問題の一般性は, 楽観的見通し, 深刻 度評価, 専門家への援助要請の必要性と, 外的原因州 属は, 楽観的見通し, 専門家への援助要請の必要性と 有意な関連を示さなかった。一方，うつ病未認知群で は, 内的原因帰属と問題の一般性は, 楽観的見通しと, 外的原因帰属は, 深刻度評価, 専門家への援助要請の 必要性と有意な正の関連を示した。しかし, 同群では, 内的原因帰属と問題の一般性は, 深刻度評価, 専門家 への援助要請の必要性と, 外的原因帰属は, 楽観的見 通しと有意な関連を示さなかった。

楽観的見通しの各変数への関連は次の通りであった。 うつ病認知群・未認知群とも, 楽観的見通しは, 深刻 度評価, 専門家への援助要請の必要性と有意な負の関 連を示した。

深刻度評価の各変数への関連は次の通りであった。 うつ病認知群・未認知群とも, 深刻度評価は, 専門家 への援助要請の必要性と有意な正の関連を示した。

\section{考察}

本研究の目的は, 大学生を対象に身近な仲のよい友 人の抑うつ症状に対する情緒的巻き込まれの恐れを測
定する尺度を作成し，その他の変数（内的原因帰属, 問題 の一般性, 外的原因㷌属, 楽観的見通し) と併せて, 抑うつ 症状を呈する友人への深刻度評価, 専門家への援助要 請の必要性と負の関連が認められるかを検証すること であった。まず，尺度作成では，因子分析の結果から， 尺度の因子構造は, 河合 (2016) による仮説的知見から 想定した 1 因子構造ではなく, うつ病認知群・未認知 群に扔いても「直面化回避志向」と「共鳴懸念」の 2 因子構造から成ると考えることが妥当であった。因子 間相関は有意な正の関連を示したが, 外的基準である 各尺度とはそれぞれ異なる関連を示した。そのため, 両因子は概念的に異なる性質を有することが示唆され た。また, 両因子とも $\alpha \geqq .78$ であり, 一定程度の $\alpha$ 係数を示し, 内的整合性の観点で一定の信頼性がある ことが示された。作成尺度のうち,「直面化回避志向」 は, うつ病認知群・未認知群にかかわらず, 抑うつ症 状を示す友人に対する楽観的見通しと有意な正の関連 を示し，深刻度評価と有意な負の関連を示した。また， うつ病認知群において,「直面化回避志向」は, 専門家 への援助要請の必要性と有意な負の関連を示した。一 方, 「共鳴䯚念」は, うつ病認知群・未認知群にかかわ らず，抑うつ症状を示す友人に対する深刻度評価と有 意な正の関連を示し予測に反した結果であった。以下 では，身近な友人の抑うつ症状に対する情緒的巻き込 まれの恐れ尺度の構造と性質, 抑うつ症状を呈する身 近な仲のよい友人への深刻度評価, 専門家への援助要 請の必要性との関連について考察する。

\section{身近な友人の抑うつ症状への情緒的巻き込まれの恐れ}

(仮説 1-1, 1-2)

作成尺度と関連が想定される構成概念との関連性の うち, 「共鳴懸念」については仮説 1-1 通りの結果が得 られたが，「直面化回避志向」については部分的な支持 にとどまった。

「共鳴懸念」も「直面化回避志向」も抑うつや不安と いった不快情動との直面の困難さを表す不快情動回避 心性尺度と有意な正の相関・偏相関を示した。「共鳴懸 念」は，抑うつ症状を呈する友人との接触を通して生 じうる自らのネガティブな認知や感情を恐れる傾向を, 「直面化回避志向」は，抑うつ症状を呈する身近な仲の よい友人と接したり向き合ったりすることを避けよう とする傾向を表す。これらを踏まえると, 両下位尺度 は自他のネガティブな認知や感情と向き合うことに対 する抵抗を表す構成概念であると考えられる。

「共鳴懸念」の尺度項目のうち, 抑うつ症状を呈する 身近な仲のよい友人との接触を通して, 自らもネガ 
ティブな感情や認知に苛まれる恐れを示す項目の因子 負荷量が相対的に高かった。また，日本語版 ACS 抑う つ尺度や感情的被影響性尺度と有意な正の相関・偏相 関を示していた。これらのことから,「共鳴懸念」は, 河合（2016）の「情緒的巻き込まれの恐れ」の定義に近 似しており，内容的に妥当であると考えられる。

「直面化回避志向」は, 自らの抑うつをコントロール できなくなるのではないかという恐れを表す日本語版 ACS 抑うつ尺度とは極めて小程度の有意な正の関連を 示し，他者からの感情的な影響の受けやすさを表す感 情的被影響性尺度とは有意な小程度の正の相関を示し ていた。しかし，「共鳴懸念」を統制すると，日本語版 ACS 抑うつ尺度とは有意な小程度の負の偏相関を，感 情的被影響性尺度とは無相関であった。つまり，抑う つ症状を呈する身近な仲のよい友人と接したり, 向き 合ったりすることを避けようと考える者ほど，自らの 抑うつを統制できるか否かについて恐れにくいが，両 者の関連は弱いと考えられる。「直面化回避志向」で は，抑うつ症状を呈する身近な仲のよい友人に対する 接触や直面化の回避を示す項目の因子負荷量が特に高 かった。このことから, 当該友人に対する接触や直面 化の回避の積極性を表しているとも解釈できる。した がって,「直面化回避志向」が高い者ほど, 当該友人と の接触を想定しにくく，接触によって自らに生じうる 抑うつを制御できるか否かを恐れる必要がないと判断 すると考えられ，このことが結果に反映された可能性 がある。以上のような解釈は可能であるが，「直面化回 避志向」の妥当性の検証は, 異なる尺度を用いて更な る検討が必要といえる。

確認的因子分析の結果, うつ病認知群 - 未認知群に かかわらず，情緒的巻き込まれの恐れという概念は 「直面化回避志向」と「共鳴懸念」の 2 因子解から成る と解釈した方が妥当であると考えられた。河合 (2016) が生成したように単一の「情緒的巻き込まれの恐れ」 ではなかったが，その定義に重なる因子 (「共鳴䯚念」) も内包されていたことから，仮説 1-2 は部分的に支持 されたといえる。先行研究 (e.g., Griffiths et al., 2006; 望月 他, 2008; 吉岡 •三沢, 2012) では, うつ病罹患者には, 統合 失調症罹患者に対して抱かれる否定的認識（危険性）と は異なる性質の認識が抱かれることが示唆されていた。 本研究で明らかにされた「共鳴懸念」と「直面化回避 志向」は，うつ病の徵候や症状を呈する者に対して抱 かれるとされる「多方面での“心配”や“不安”」(吉 岡·三沢, 2012, p. 100) の一端であり，それを実証的に明 らかにしたといえる。

\section{仮説 2 (仮説 2-1, 仮説 2-2) について}

「共鳴懸念」は, うつ病認知群では, 内的原因帰属と 有意な負の関連を，問題の一般性と有意な正の関連を 示した。また, うつ病未認知群では, 楽観的見通しと 有意な負の関連を示し, 内的原因㷌属, 問題の一般性 との間に有意な関連を示さなかった。さらに, うつ病 認知群・未認知群両群に扔いて, 深刻度評価と有意な 正の関連を示し, 専門家への援助要請の必要性との間 に有意な関連を示さなかった。一方, 「直面化回避志 向」は, うつ病認知群・未認知群とも, 内的原因帰属, 楽観的見通しと有意な正の関連を, 深刻度評価と有意 な負の関連を示した。しかし, 問題の一般性との間に は有意な関連を示さなかった。また，うつ病認知群の み, 専門家への援助要請の必要性と有意な関連を示し た。以上から,「共鳴懸念」については, 仮説 2-1 及び 仮説 2-2 に反した結果が多く得られ, 「直面化回避志 向」については, 仮説 2-1 及び仮説 2-2 を概ね支持す る結果が得られた。つまり, 河合 (2016) の仮説的知見 については, 情緒的巻き込まれの恐れのうち, 抑うつ 症状を呈する身近な友人に直面することを回避しょう とする側面が, 当該友人の深刻さの過少評価につなが ると修正できる。

「共鳴懸念」に関して, 仮説通りの結果が得られな かった理由として，その性質による影響が考えられる。 上述の通り,「共鳴懸念」は, 日本語版 ACS 抑うつ尺 度や感情的被影響性尺度と有意な正の相関 - 偏相関を 示していた。また，日本語版 ACS 抑うつ尺度は，抑う つ尺度得点が高い者ほど, 問題解決・サポート希求 (情 報収集, 計画立案, カタルシス）という対処方略を意図しや すい (金築他, 2010)。つまり, うつ病認知群・未認知群 にかかわらず, 抑うつ症状を呈する友人との接触を通 して，自らもまたネガティブな認知や感情に苛まれる ことを恐れる大学生は，そのような感情を統制できな くなることを恐れ，当該友人から感情的に影響を受け やすいことから, 自らが積極的に関わって対処するこ とが困難であると判断したと解釈できる。このことが, 「共鳴懸念」は楽観的見通しと有意な負の関連あるいは 無相関を, 深刻度評価と有意な正の関連を示し, 専門 家への援助要請の必要性とは無相関であった結果に反 映された可能性がある。このように，「共鳴懸念」は， 仮説に反し, うつ病未認知群では, 抑うつ症状を呈す る身近な友人に対する楽観的見通しを抑制し，うつ病 認知群・未認知群の両群では, 深刻度評価を促しうる ことが示唆された。深刻度評価は, 専門家への援助要 請の必要性に有意な正の関連を示していたことを踏ま 
えると, 大学生のメンタルヘルスの保持の観点から, 「共鳴懸念」はむしろ必要な懸念であるとも捉えられ る。Joiner (1994) は, 抑うつ的な人と交流がある者は, そうでない者に比べ，自分もまた抑うつ的になりやす いとしている。そのため, 大学生のうつ病の早期発見 の援助資源として一般大学生を機能させることを目的 とした予防的介入の際は，低減すべき対象として「共 鳴懸念」を位置づけるべきとは言い難い。むしろ，「共 鳴懸念」が生じること自体は自然なこととし, その作 用を伝えた方が, 抑うつ症状を呈する身近な友人への 援助に繫がる可能性がある。

「直面化回避志向」については, 両群にて問題の一般 性と, うつ病未認知群では専門家への援助要請の必要 性と無相関であり，これらは仮説に反する結果であっ た。「直面化回避志向」は身近な友人の抑うつ症状に向 き合うことへの回避であるため, その症状が大学生に 一般的か, 特にうつ病に関する知識を十分に有してい ないと考えられるうつ病未認知群では専門的な援助を 要するか否かを検討するまでには至らなかった可能性 がある。一方, うつ病認知群では, 「直面化回避志向」 は，抑うつ症状を呈する身近な友人への援助に繋がら ないことが示唆され, 介入対象となりうる。大学生の うつ病の早期発見において, 一般大学生を援助資源と して活用する場合，その予防的介入においては，うつ 病に関するリテラシーの向上を図ることが基本といえ る。しかし, 本研究の結果, うつ病を認知できる大学 生でも, 「直面化回避志向」が強い者は, 抑うつ症状を 呈する身近な友人の状態を楽観的に捉え, 深刻視せず, 専門家による援助が必要であるとは考えていなかった。 つまり, うつ病のリテラシーの向上だけでは, うつ病 の早期発見の援助資源として機能するとは限らない可 能性がある。うつ経験者は, 自らのうつについて家族 や友人に援助を求めた際, スティグマ的対応を経験し たと報告されている (Griffiths, Crisp, Barney, \& Reid, 2011)。 具体的には, 自ら乗り越えるよう求められたり, 自ら のうつを受容してもらえなかったり, 軽葽や中傷や嘲 笑や非難を受けたりすることなどの対応を指し, 自ら のうつを身近な周囲に援助を求める際のデメリットと して位置づけられている（Griffiths et al., 2011）。「直面化 回避志向」を低減する介入として，こうした知見を伝 えることが一案として考えられる。

\section{仮説 3 (仮説 3-1) について}

内的原因帰属は, うつ病認知群では, 楽観的見通し と有意傾向の正の関連が, うつ病未認知群では, 楽観 的見通しと有意な正の関連が示された。しかし, 両群
とも, 深刻度評価, 専門家への援助要請の必要性と有 意な関連が示されなかった。また, 問題の一般性は, うつ病未認知群においてのみ, 楽観的見通しと有意な 正の関連を示した。さらに, 外的原因帰属は, うつ病 認知群 - 未認知群とも深刻度評価と, うつ病未認知群 においてのみ専門家への援助要請の必要性と有意な正 の関連を示した。以上から, 仮説 3-1に関して, 内的 原因帰属および外的原因帰属については部分的に支持 され, 問題の一般性については一部を除き仮説に反し た結果が多く得られた。

両群において, 内的原因帰属と深刻度評価, 専門家 への援助要請の必要性との間に有意な関連が示されな かった理由として, 内的原因帰属の捉え方の影響が考 えられる。Cook \& Wang (2011) は, うつ病は神経質な 人がなるという考え方に加え, 心理社会的要因に原因 帰属をする人ほど, うつ病罹患者に対して「望めば, 憂うつな気分から抜け出せる」という認識を抱きやす いとしている。一方, うつ病は神経質な人がなるとい う考え方に加え, うつ病を心理社会的要因や遺伝的要 因あるいは化学物質の不均衡に原因帰属をする人はそ のような認識を抱くわけではなかったとしている。本 研究の内的原因帰属に関する質問項目では, 性格を指 すのか, 気質を指すのか, 遺伝的要因を指すのか具体 的に問わなかった。そのため, うつ病認知群の中にう つ病の原因論について, 異なる立場の者が混在し, 深 刻度評価, 専門家への援助要請の必要性への関連が相 殺された可能性がある。今後は, うつ病に対する内的 原因帰属を細分化した上での検討が必要だろう。

また, 問題の一般性については, 特にうつ病認知群 において仮説に反した結果が多く示された。Welchの $t$ 検定の結果から, うつ病認知群は, うつ病未認知群 に比べうつ病事例のような状態を大学生によくある 問題とはみなさず, 楽観的には捉えないことが示唆さ れた。また, うつ病未認知群に比べ, うつ病事例は深 刻であり, 専門家への援助要請が必要であると考えや すいことが示唆された。つまり, うつ病認知群にとつ て, うつ病事例のような状態は大学生によくある問題 ではなく, むしろ, 予後が楽観的ではない深刻な状態 であり, 専門家の援助を要する状態と認識していたと 考えられる。そのため, うつ病認知群においては, 問 題の一般性と, 楽観的見通しや深刻度評価や専門家へ の援助要請の必要性とを結びつけて考えにくかった可 能性がある。したがって, 仮説の通りの関連が示され なかったと解釈できる。

外的原因帰属は, うつ病認知群 - 未認知群とも深刻 
度評価と有意な正の関連を示しており, 先行研究の結 果 (e.g., 吉岡・三沢, 2012) と同様の結果が確認された。 つまり，身近な仲のよい友人が，抑うつ症状を呈した 場合，その原因を当該友人の外側の環境や出来事にあ ると帰属する大学生ほど, 当該友人を深刻に捉えやす いことが示唆される。また, うつ病未認知群において のみ, 専門家への援助要請の必要性とも有意な正の関 連を示していたが，その標準化推定值は.10未満であ り，ほほ関連がないといえる。つまり，抑うつ症状を 呈する身近な友人をうつ病にかかっているとは認知し ない大学生ほど, 専門家に援助要請する必要があると 考えやすいが，その傾向は弱いといえる。うつ病の原 因帰属に関する諸研究では, 外的原因帰属として, 最 近のトラウマになる出来事, 身近な友人や親族の死, 幼少期の問題, 日々のストレスフルな問題が挙げられ ている (e.g., Cook \& Wang, 2011; 吉岡 •三沢, 2012)。本研究 では, 外的原因を詳細化していなかったため, 個々の 回答者がそれぞれに外的原因を想起していた可能性が ある。そのため, 想定した外的原因が楽観的に見通せ るものか否か, 専門家による援助を要するか否かを評 価し難いものもあれば，それらが評価しやすいものも あったと考えられる。この点が両群にて外的原因帰属 と楽観的見通しが, うつ病認知群では外的原因帰属と 専門家への援助要請の必要性が無相関であり, うつ病 未認知群では両変数の間にほぼ関連が示されなかった という結果に反映されたと解釈できる。

以上の結果から, 特に, 抑うつ症状を呈する身近な 友人への楽観視に繫がる原因帰属への介入が重要とい える。現在, うつ病の発症と維持の過程においては, 生物学的要因と心理社会的要因が相互に関連し合って いることが仮定されている (e.g., 日本うつ病学会気分障害 の治療ガイドライン作成委員会, 2016)。うつ病の発症および 維持要因は多様であり, それらが複雑に絡み合ってい ることを示し，うつ病の原因に関して一面的な理解に とどまらないよう意識させることが重要である。

\section{仮説 3 (仮説 3-2) について}

仮説 3-2 の通り, 楽観的見通しは, うつ病認知群 . 未認知群において, 深刻度評価および専門家への援助 要請の必要性と有意な負の関連が認められた。また, 深刻度評価も, 両群とも専門家への援助要請の必要性 と有意な正の関連が認められた。つまり，うつ病認知 群・未認知群とも，抑うつ症状を呈する友人は, 時間 が経てば良くなると考えたり，自力で解決できると考 えたりする大学生ほど, 当該友人の深刻さや専門家へ の援助要請の必要性を低く見積ると考えられる。また,
そのように，当該友人を深刻であると評価する大学生 ほど, 当該友人は専門家に援助要請する必要があると 認識すると考えられる。特に, 深刻度評価と専門家へ の援助要請の必要性の間の関連性は, 梅垣 (2014) の結 果と矛盾しない結果といえる。

これらの結果を踏まえると, 一般大学生向けのうつ 病に関する予防的介入に括いては, うつ病の状態, 徵 候や症状を呈する者を楽観的に捉えるリスクを意識さ せる情報伝達が必要である。例えば, 抑うつ症状を呈 する大学生は, 学業上の支障 (American College Health Association, 2008), 自殺のリスク (Uchida \& Uchida, 2017) を抱え，その身近な周囲も悪影響を受ける (e.g., Joiner, 1994）といったことを伝達し，楽観的に見通さないよう 伝えることが重要である。

\section{本研究の限界と今後の課題}

本研究の限界と課題として次の四点が挙げられる。 第一に, 作成尺度の再検査信頼性を検討できていない 点である。本尺度は, 内的整合性の高さが示されたも のの, 時間的安定性については定かではない。今後は 本尺度の再検查信頼性についても検討し, 時間的安定 性を備えた尺度であるかを確認する必要がある。第二 に, 「直面化回避志向」と「共鳴懸念」が, 大学生以外 の年齢や社会集団にも一般化可能であるか検討するこ とである。第三に, 本研究は横断研究のため, 変数間 の関連の因果性には積極的には言及できない点である。 また, 標準化推定值の值が決して大きくない点を踏ま えると, その関連性の強さの解釈には慎重を来す必要 がある。第四に, 本研究では, 友人の性別を定めてい ない点である。本研究は, 身近な友人の抑うつ症状へ の情緒的な巻き込まれの恐れを測定する尺度の作成と， 関連変数との関連性を検証することを主目的としてい たため, 友人の性別は要因として組み込まなかった。 しかし, 回答者が想定した友人の性別によっては結果 に影響を及ぼしていた可能性もある。今後は想定する 友人の性別を含めた検討が必要である。

以上のような限界はあるものの, 本研究は, 大学生 は，うつ病認知の可否を問わず，抑うつ症状を呈する 身近な仲のよい友人に対して情緒的な巻き込まれの恐 れを抱くことを明らかにし, うつ病の徴候や症状を呈 する者に向けられる「多方面での “心配”や“不安”」 （吉岡・三沢, 2012, p. 100）の一端を示したことに意義があ るといえる。また, 情緒的巻き込まれの恐れが当該友 人への認識・評価に作用することを明らかにし, 大学 生を対象としたうつ病の早期発見を目的とした予防的 介入における介入対象を見出した点も本研究の意義で 
ある。援助提供者を対象としたメンタルヘルスの教育 的プログラムがほとんどない (Griffiths et al., 2011) 現状 に対して，本研究は介入の基礎資料を提供したといえ る。

今後の展望として, 抑うつ症状を呈する身近な友人 への情緒的巻き込まれの恐れと多様な援助行動意図と の関連性を検討することが挙げられる。うつ病をはじ めとする精神障害を発病した者が，専門家からの支援 を受ける前に身近な周囲から受ける初期支援をメンタ ルヘルス・ファーストエイドと呼ぶ (Kitchener \& Jorm, 2002 メンタルヘルス・ファーストエイド・ジャパン編訳 2012)。 具体的には,「自傷他害のチェックをする」,「判断, 批 判せずに話を聴く」，「安心と情報を与える」，「適切な サポートを求めるよう勧める」,「セルフヘルプを勧め る」が提唱されている。今後は，身近な友人の抑うつ 症状への情緒的巻き込まれの恐れが，これらの初期支 援行動意罒にどのように関連するかを検討することが 必要である。

\section{引用文献}

Amarasuriya, S. D., Reavley, N. J., Rossetto, A., \& Jorm, A. F. (2017). Helping intentions of undergraduates towards their depressed peer: A cross-sectional study in Sri Lanka. BMC Psychiatry, 17, 40. doi:10.1186/ s12888-017-1192-7

American College Health Association (2008). American College Health Association-National College Health Assessment: Reference group data report, Spring 2008. Baltimore, MD: Author.

Cook, T. M., \& Wang, J. (2011). Causation beliefs and stigma against depression: Results from a populationbased study. Journal of Affective Disorders, 133, 86-92. doi:10.1016/j.jad.2011.03.030

Eisenberg, D., Golberstein, E., \& Gollust, S. E. (2007). Help-seeking and access to mental health care in a university student population. Medical Care, 45, 594-601. doi:10.1097/MLR.0b013e31803bb4c1

福森崇貴・小川俊樹 (2005). 不快情動回避心性尺度の 作成 筑波大学心理学研究, 29, 125-130.

Goldstein, B., \& Rosselli, F. (2003). Etiological paradigms of depression: The relationship between perceived causes, empowerment, treatment preferences, and stigma. Journal of Mental Health, 12, 551-563. doi:10.1080/09638230310001627919

Griffiths, K. M., Christensen, H., Jorm, A. F., Evans, K.,
\& Groves, C. (2004). Effect of web-based depression literacy and cognitive behavioural therapy interventions on stigmatizing attitudes to depression: Randomised controlled trial. British Journal of Psychiatry, 185, 342-349. doi:10.1192/bjp.185.4.342

Griffiths, K. M., Crisp, D. A., Barney, L., \& Reid, R. (2011). Seeking help for depression from family and friends: A qualitative analysis of perceived advantages and disadvantages. BMC Psychiatry, 11, 196. doi: 10.1186/1471-244X-11-196

Griffiths, K. M., Nakane, Y., Christensen, H., Yoshioka, K., Jorm, A. F., \& Nakane, H. (2006). Stigma in response to mental disorders: A comparison of Australia and Japan. BMC Psychiatry, 6, 21. doi:10.1186/ 1471-244X-6-21

Ibrahim, A. K., Kelly, S. J., Adams, C. E., \& Glazebrook, C. (2013). A systematic review of studies of depression prevalence in university students. Journal of Psychiatric Research, 47, 391-400. doi:10.1016/j. jpsychires.2012.11.015

Joiner, T. E., Jr. (1994) . Contagious depression: Existence, specificity to depressed symptoms, and the role of reassurance seeking. Journal of Personality and Social Psychology, 67, 287-296. doi:10.1037/00223514.67.2.287

Jorm, A. F., Blewitt, K. A., Griffiths, K. M., Kitchener, B. A., \& Parslow, R. A. (2005). Mental health first aid responses of the public: Result from an Australia national survey. BMC Psychiatry, 5, 9. doi:10.1186/ 1471-244X-5-9

Jorm. A. F., Wright, A., \& Morgan, A. J. (2007). Beliefs about appropriate first aid for young people with mental disorders: Findings from an Australian national survey of youth and parents. Early Intervention in Psychiatry, 1, 61-70. doi:10.1111/j.1751-7893.2007. 00012.x

金築 優 · 金築智美 · 及川昌典 (2010). 感情への恐れ とストレス反応の関連性一日本語版Affective Control Scale の作成を通して 感情心理学研究, 18, 42-50. doi:10.4092/jsre.18.42

樫原 潤 ・河合輝久・梅垣佑介 (2014). うつ病罹患者 に対するスティグマ的態度の現状と課題一潜在尺度 の利用可能性への着目 心理学評論, 57, 455-471. doi:10.24602/sjpr.57.4_455

加藤隆勝 - 高木秀明 (1980). 青年期における情動的共 
感性の特質 筑波大学心理学研究, $2,33-42$.

河合輝久 (2016). 大学生は身近な友人の心理的問題を どのように見過ごすか一友人の抑うつ症状の見過ごし

に関する質的研究 学生相談研究, 37, 12-26.

河合輝久 (2019). 大学生のうつ病に対する認知および ファーストエイド方略 心理学研究, 90, 42-52. doi: 10.4992/jjpsy.90.17235

Kim, J. E., Saw, A., \& Zane, N. (2015). The influence of psychological symptoms on mental health literacy of college students. American Journal of Orthopsychiatry, 85, 620-630. doi:10.1037/ort0000074

木村真人 (2015). 大学生の学生相談利用におけるパー ソナル・サービス・ギャップ一抑うつ症状の場面想 定法を用いた検討 心理臨床学研究, 33, 275-285.

Kitchener, B., \& Jorm, A. (2002). Mental health first aid manual. ORYGEN Research Centre, Melbourne, Australia. (キッチナー, B.・ジョーム, A. メンタル ヘルス・ファーストエイド・ジャパン（編訳） (2012). 専門家に相談する前のメンタルヘルス・ ファーストエイドーこころの応急処置マニュアル 創元社)

Messick, S. (1995). Validity of psychological assessment: Validation of inferences from persons' responses and performances as scientific inquiry into score meaning. American Psychologist, 50, 741-749. doi:10.1037/0003-066X.50.9.741

望月美栄子 - 山崎喜比古 · 菊澤佐江子 · 的場智子 · 八 巻知香子・杉山克己・坂野純子 (2008).こころの病 をもつ人々への地域住民のスティグマおよび社会的 態度一全国サンプル調査から 厚生の指標, 55, 6-15.

中村菜々子 ・ 久田 満 (2008). 企業の従業員における メンタルヘルス・リテラシーーうつ症状に関する知 識と対処行動の実行可能性を中心に コミュニティ 心理学研究, 12, 23-34.

日本うつ病学会気分障害の治療ガイドライン作成委員 会 (2016). II .うつ病 (DSM-5)/大うつ病性障害 2016 日本うつ病学会治療ガイドライン Retrieved from https://www.secretariat.ne.jp/jsmd/iinkai/kat sudou/data/160731.pdf (2019 年 11 月 7 日)

西村由貴 - 岩佐好恵 - 田中由紀子 - 藤井 香 - 高山昌子 (2008). 大学生のメンタルヘルス調査 2008一うつ 病・社交恐怖・自殺の危険の時点および 12 ケ月有病 率 慶應保健研究, 27, 41-45.

Reavley, N., \& Jorm, A. (2014). Associations between beliefs about the causes of mental disorders and stigmatizing attitudes: Results of a national survey of the Australian public. Australian \& New Zealand Journal of Psychiatry, 48, 764-771. doi:10.1177/0004867414 528054

Reavley, N., McCann, T., \& Jorm, A. (2012). Mental health literacy in higher education students. Early Intervention in Psychiatry, 6, 45-52. doi:10.1111/ j.1751-7893.2011.00314.x

Spendelow, J. S., \& Jose, P. E. (2010). Does the optimism bias affect help-seeking intentions for depressive symptoms in young people? Journal of General Psychology, 137, 190-209.

Uchida, C., \& Uchida. M. (2017). Characteristics and risk factors for suicide and deaths among college students: A 23-year serial prevalence study of data from 8.2 million Japanese college students. Journal of Clinical Psychiatry, 78, 404-412. doi:10.4088/ JCP.16m10807

梅垣佑介（2014）.うつと援助をつなぐ一援助資源マッ チングに向けた臨床心理学研究 東京大学出版会

梅垣佑介・木村真人 (2012). 大学生の抑うつ症状の援 助要請における楽観的認知バイアス 心理学研究, 83, 430-439. doi:10.4992/jjpsy.83.430

梅垣佑介・末木 新 (2012). 抑うつ症状に関する援助 希求行動における楽観的認知バイアスとその関連要 因 精神医学, 54, 287-296.

Williams, K. E., Chambless, D. L., \& Ahrens, A (1997). Are emotions frightening? An extension of the fear of fear construct. Behaviour Research and Therapy, 35, 239-248. doi:10.1016/S0005-7967 (96) 00098-8

Yap, M., \& Jorm, A. (2011). The influence of stigma on first aid actions taken by young people for mental health problems in a close friend or family member: Findings from an Australian national survey of youth. Journal of Affective Disorders, 134, 473-477. doi: 10.1016/j.jad.2011.05.039

Yap, M., Reavley, N., \& Jorm, A. (2015). Is the use of accurate psychiatric labels associated with intentions and beliefs about responses to mental illness in a friend? Findings from two national surveys of Australian youth. Epidemiology and Psychiatric Sciences, 24, 54-68. doi:10.1017/S2045796013000607

Yap, M., Wright, A., \& Jorm, A. (2011). The influence of stigma on young people's help-seeking intentions and 
beliefs about the helpfulness of various sources of help. Social Psychiatry and Psychiatric Epidemiology, 46, 1257-1265. doi:10.1007/s00127-010-0300-5 吉岡久美子·三沢 良 (2012). 精神疾患に関するス ティグマの影響モデルの検証一うつ病の原因帰属と 社会的距離の関連性 健康心理学研究, 25, 93-103. doi:10.11560/jahp.25.1_93

$$
\text { 付 記 }
$$

活動スタート支援, 課題番号：JP16H06708）の助成を 受けて実施された。また, 本研究は, 2018 年度に東京 大学大学院教育学研究科に提出した博士論文の一部を 加筆修正しまとめ直したものである。

本論文の執筆にあたり，ご指導いただきました下山 晴彦先生に心より御礼申し上げます。また, 本研究に ご協力いただきました皆様, 查読者の先生方に深謝申 し上げます。

(2018.9.19 受稿, 2019.6.21 受理)

本研究は, 日本学術振興会科学研究費補助金（研究

\title{
Fear of Emotional Over-Involvement With Depressed Friends in Relation to Optimistic Prognosis, Severity, and Need for Help-Seeking
}

\author{
TERUHISA KAWAI (YAMAGATA UNIVERSITY) \\ JAPANESE JOURNAL OF EDUCATIONAL PSYCHOLOGY, 2019, 67, 289-303
}

The present study examined impact of the fear of emotional over-involvement with a close friend who is depressed on evaluation of the severity and prognosis of the friend's problems, the friend's need to seek help from a student counseling service, and related factors. A scale was developed to measure fear of emotional over-involvement with depressed friends, and the scale's internal consistency and validity were examined. The results of a factor analysis revealed that the 9 items in the scale were comprised of 2 factors: fear of contagious depression and tendency to avoid confrontation. The scale had acceptable internal consistency and validity. The main results of structural equation modeling were that, regardless of participants' ability to identify depression, (a) the tendency to avoid confronting a friend's depression was positively correlated with an optimistic prognosis for the friend, and negatively correlated with the respondent's rating of the severity of the friend's depression, and (b) fear of contagious depression was correlated positively with the respondent's rating of the severity of the friend's problem. These findings suggest that university students who tend to avoid confronting depressed friends may underestimate their friends' symptoms of depression, whereas those who fear contagious depression may not underestimate them.

Key Words: university students' friends, university students, symptoms of depression, fear of emotional overinvolvement 